\title{
80-lecie urodzin profesora dra hab. Bronisława Jasickiego
}

\author{
Pawel Sikora
}

80TII BIRTIDAY OF PROFESSOR BRONISLAW JASICKI. He was born on the 12th of January 1907. and since 1928 has worked at the Jagellonian University. He is an author of numerous worlis. mainly on ontogenesis of man. and leacher of many Polish anthropologisls.

12 stycznia 1987 r. profesor dr hab. Bronislaw Jasicki ukończyl 80 lat życia, z którego prawie 60 lat poświęcil nauce.

Bronisław Jasicki urodzil się w Sporyszu (na Żywiecczyźnie) w rodzinie nauczyciela szkoly podstawowej. Swiadectwo dojrzalości uzyskał w 1924 r. w Gimnazjum Matematyczno-Przyrodniczym im. M. Kopernika w Żywcu. W tym samym roku zapisal się na Wydzial Filozoficzny Uniwersytetu Jagiellońskiego i studiowal nauki przyrodnicze do roku 1929, w którym uzyskal alssolutorium. Panistwowy dyplom nauczycielski, który potwierdzal pelne kwalifikacje do mauczania w szkolach średnich uzyskal w r. 1933.

Bronislaw Jasicki już jako student interesowall się wykladami $z$ antropologii. prowadzonymi przez wylitnego uczonego, profesora Juliana Talko-Hryncewicza. Od 1 XII 1928 r., będąc jeszcze studentem

Zaklad Aneropologii U.I ul. Karasia 6, 30-060 Krakow został mianowany mlodszym asystentem przy Zakladzie Antropologii Uniwersytetu Jagiellońskiego. Pierwszą prace naukowa wykonal pod kierunkiem J. TalkoHryncewiczal. Nosila ona tytul "Trwanie życia górali polskich od r. 1881 do 1925" i byla wydrukowana w wydawnictwach Polskiej Akademii Umiejętności w r. 1930. Na podstawie tej pracy. opartej na wypisach z ksiag metrykalnych $z$ dawnych powiatów żywieckiego i nowotarskiego (lacznie z 16 parafii), Bronislaw Jasicki uzyskal w r. 1931 tytul doktora filozofii. Temat pracy nie wynikal bezpośrednio z zainteresowan autora - mlodego adepta antropologii, ale odzwierciedlal problematykę, nad którą pracowal kierownik Zakladu Antropologii - profesor Talko-Hryncewicz.

Prace naukowe Bronisława Jasickiego. które zaczęly powstawać po uzyskaniu przez niego doktoratu, dotyczyly zagadnień czysto antropologicznych. Zainteresowania ich autora koncentrowaly się glównie na rozwoju ontogenetycznym 
czlowieka, ale także na morfologicznym zróżnicowaniu czlowieka współczesnego i częściowo - kopalnego. Zajmowal się on również metodami analitycznymi w antropologii oraz historią antropologii w Krakowie.

Najliczniejsze byly prace na temat rozwoju ontogenetycznego czlowieka - głównie mlodzieży krakowskiej. Badania nad rozwojem młodzieży zapoczątkował w Krakowie J. Talko-Hryncewicz już w r. 1908 i prowadzil je do r. 1932, to jest do swego ustąpienia z kierownictwa Zakladu Antropologii. Bronisław Jasicki już jako student włączył się do powyższych badań i glównie on materiały te opracowywał. $\mathrm{Na}$ ich podstawie, oprócz kilku drobniejszych, wykonal trzy podstawowe i prekursorskie prace. Pierwszą byla "Dynamika rozwoju męskiej mlodzieży szkolnej z Krakowa" (Prace i Materialy Antropologiczne PAU, t. I, Kraków 1938). Na podstawie materialów ciągłych opracowal w niej dynamikę wzrastania wysokości ciala, wymiarów glowy i twarzy oraz wskaźników glowy, twarzy i nosa. Rozwój poszczególnych cech opracował dla calości materiału, oraz w wyodrębnionych zespołach morfologicznych wykazując, że zmienność cech morfologicznych w wyodrębnionych zespolach przebiega zasadniczo tak samo, jedynie czas przyspieszonego rozwoju jest różny.

W r. 1936 Bronislaw Jasicki otrzymal etat starszego asystenta, który zajmował do 1939 r. Z chwilą wybuchu wojny Uniwersytet Jagielloński zostal zamknięty, zaś ówczesny kierownik Zakladu Antropologii, prof. dr Kazimierz STOLYHWo, podzielil los innych profesorów UJ - został aresztowany i wywieziony do obozu koncentracyjnego. Dr Bronisław Jasicki wraz z innymi pracownikami sprawowal opiekę nad Zakladem Antropologii, oczywiście bez jakiegokolwiek wynagrodzenia, aż do momentu jego likwidacji w r. 1940. Dr Bronislaw Jasicki musial podjąć pracę w firmie budowlanej jako robotnik niekwalifikowany, a następnie w Institut für Fleckfieber und Virus Forschund w charakterze siły technicznej na oddziale zakaźnym, gdzie pracowal aż do końca wojny.

Bezpośrednio po oswobodzeniu Krakowa dr Bronislaw Jasicki zglosil się do Uniwersytetu Jagiellońskiego na zajmowane poprzednio stanowisko starszego asystenta. Po zorganizowaniu Zakladu Antropologii UJ w tymczasowym pomieszczeniu przy ul. św. Anny, dr Jasicki rozpocząl pracę naukową kontynuując problematykę ontogenetyczną. W r. 1946 (28.1) habilitowal się na podstawie pracy "Dynamika rozwojowa męskiej mlodzieży z Krakowa", a w r. 1948 oglosil pracę "Dalsze badania nad dynamiką rozwojową mlodzieży szkolnej" (Prace i Materiały Antropologiczne PAU, t. 2, nr 2, Kraków). W pracach tych poddaje szczególowej analizie zmienność cech morfologicznych w badanym odcinku wieku rozwojowego $\mathrm{w}$ wyodrębnionych zespolach antropologicznych.

W pracy zatytulowanej "Zjawisko dojrzewania a wysokość ciala u chlopców" (Przegląd Antropologiczny, t. 15, 1948, Poznań), Bronislaw Jasicki opisal przebieg linii rozwojowych $w$ zakresie wysokości ciała w związku ze skokiem przedpokwitaniowym. Warto przypomnieć, że zjawisko to opisal Bronislaw Jasicki w roku 1948, podczas gdy cytowany przez wszystkich Tanner podaje jego opis w swoim podręczniku dopiero w roku 1955.

W roku 1946 Bronislaw Jasicki zostal mianowany adiunktem przy Zakladzie Antropologii UJ, a od r. 1951 - adiunktem habilitowanym. Na stanowisko samodzielnego pracownika naukowego powolany zostal w 1956 r., w r. 1963 zostal profe- 
sorem nadzwyczajnym, zaś w r. 1972 profesorem zwyczajnym. W r. 1965 profesor Jasicki zostaje kierownikiem Zakladu Antropologii UJ i pełni tę funkcję do $1976 \mathrm{r}$. W latach 1967 do 1970 byl ponadto dyrektorem Instytutu Zoologicznego UJ.

Oprócz pracy w Uniwersytecie Jagiellońskim Bronislaw Jasicki prowadzil wyklady w Wyższej Szkole Pedagogicznej w Krakowie (w roku akademickim 1950/51) oraz na Wydziale Biologii i Nauk o Ziemi Uniwersytetu Toruńskiego (w latach 19511955). Równocześnie z pracą w Zakladzie Antropologii UJ podjąl pracę dodatkową w Wyższej Szkole Wychowania Fizycznego w Krakowie. W 1954 r. powolany zostal na kierownika Katedry Biologii i Antropologii WSWF, zaś w r. 1959 wybrany zostal rektorem tej uczelni. $\mathrm{Z}$ chwilą powolania go na kierownika Zakladu Antropologii UJ w r. $1965 \mathrm{z}$ obu tych funkcji zrezygnowal.

W latach sześćdziesiątych profesor Jasicki znacznie rozszerzyl problematykę z zakresu ontogenezy czlowieka, a to dzięki temu, iż dwukrotnie wziąl udzial w badaniach antropologicznych na terenie Egiptu (w latach 1959/60 i w 1962). Zgromadzono wówczas bogate materialy dotyczące rozwoju mlodzieży, zarówno $z$ osiedli polożonych na pustyni, w dolinie Nilu, jak i w oazach. Z zakresu rozwoju ontogenetycznego mlodzieży egipskiej profesor Jasicki oglosił kilka prac. Porównując materiały polskie z egipskimi mial możliwość wysunięcia pewnych koncepcji dotyczących wplywu ruchu na tempo zmian w proporcjach ciala.

Jedną z ostatnio wydanych prac z zakresu badań nad rozwojem mlodzieży jest "Trend sekularny dzieci i mlodzieży szkól miasta Żywca. Monografia antropologiczna Żywiecczyzny" (Zeszyty Naukowe Uniwersytetu Jagiellońskiego, Prace Zoologiczne, zesz. 31, Kraków,
1986 r.). Materialy do tej pracy pochodzą z badań antropologicznych Żywiecczyzny zorganizowanych przez Bronislawa Jasickiego i prowadzonych pod jego kierownictwem od roku 1962 do dzisiaj. Badaniami objęto nie tylko mlodzież szkolną ale i dorosłych. W niektórych miejscowościach badania mlodzieży powtarzane są co 10 lat.

Odrębną dziedziną badań Bronislawa Jasickiego są zagadnienia związane $z$ różnicowaniem się form ludzkich, glównie wspólczesnych. Zagadnieniom tym poświęcil on kilka publikacji. Można tu wspomnieć o pracy dotyczącej morfologii żuchwy czlowieka wspólczesnego oraz paleolitu mlodszego. Praca ta byla referowana przez profesora K. Stolyhwę na Międzynarodowym Kongresie Antropologicznym i Etnologicznym w Londynie w 1934 r. Szereg publikacji poświęcil Bronislaw Jasicki strukturze antropologicznej górali i podgórzan polskich.

W prowadzonych w latach pięćdziesiątych dyskusjach taksonomicznych wziąl udzial również Bronislaw Jasicki, publikując, razem z Kazimierzem i Eugenią Stolyhwami kilka artykułów dotyczących analizy antropologicznej.

Istotny jest wklad Bronislawa Jasickiego w stworzenie znanego polskiego podręcznika antropologii (Zarys Antropologii, red. E. Stolyhwowa, Warszawa 1962). Opracowal on rozdzialy dotyczące stanowiska czlowieka wśród kręgowców, zróżnicowania cech czlowieka na tle ich zmienności u naczelnych i rozmieszczenia wspólczesnych ras ludzkich na świecie.

Wielu spośród pracujących obecnie w Polsce antropologów swoją wiedzę i awans naukowy zawdzięcza w jakiejś mierze profesorowi Jasickiemu. Pod jego bezpośrednim kierunkiem wykonano 190 prac magisterskich. Byl on promotorem 17 prac 
P. Sikora

doktorskich, uczestniczyl w 9 postępowaniach habilitacyjnych, opracowal wiele recenzji i opinii związanych z nadawaniem stopni i tytulów naukowych.

$\mathrm{Za}$ ponad pólwieczna działalność, której efektem jest olbrzymi wklad w rozwój polskiej antropologii, należą się Profesorowi wyrazy wdzięczności oraz życzenia wielu jeszcze lat twórczego uczestnictwa w życiu naukowym, zapewniającego możliwość korzystania z Jego dorobku i doświadczeń.

Maszynopis nadeslano w styczniu 1987 t.

\section{S u m m a r y}

Professor Bronislaw JASICKI was born in Sporysz on the 12th of January 1907. Since 1928 he has worked at the Jagellonian University, at first under the direction of Professor J. Talko-Hryncewicz, then Professors Kazimierz and Eugenia Stołyhwo. He devoted his entire life to anthropology. He directed and participatcd in research projects in ontogenetics (including research on the population of the Żywiec region). Hc is an author of numerous and original works in this field. For many years he was the head of the Anthropology Division of the Jagellonian University. He educated many anthropologists as a promotor and revicwer of numerous master theses, doctoral dissertations and works qualifying for the position of an assistant proficssor and professor. He has made an invaluable contribution to the development of Polish anthropology. 